\title{
Bog noter
}

Af Vibeke Sperling

Allers, Roberts m.fl. (red.):

Common or Divided Security? German and Norwegian Perspectives on Euro-Atlantic Security. Peter Lang International Academic Publishers, 2014.

25 år efter afslutningen på den kolde krig er euroatlantisk sikkerhed under pres, hedder det $\mathrm{i}$ introduktionen til bogen, der behandler de største udfordringer for vestlig sikkerhed ud fra to europæiske allieredes perspektiv: Tysklands og Norges og hvordan de angriber behovet for at omtænke den fælles sikkerhedsstruktur. At forsømme den opgave kan ifølge bogen presse Vesten tilbage til delt sikkerhed, fragmentering og gennationalisering af sikkerhed. Hvis de større geopolitiske ændringer skal besvares, må både $\mathrm{EU}$ og Nato bibringes ny energi og visioner, fremhæver forfatterne.

Al-Ali, Zaid:

The Struggle for Iraq's Future: How Corruption, Incompetence and SectarianismHave Undermined Democracy. Yale University Press, 2014.

Mange vestlige skribenter har behandlet udviklingen i Iraks statsdannelse ef- ter invasionen i 2003 og konsekvenserne af amerikansk tilbagetrækning, mens der kun er skrevet lidt om irakerne selv. Denne bog søger at udfylde det tomrum. Forfatteren er en irakisk advokat med tæt kontakt til befolkningen, irakiske regeringskredse og internationale ledere. Det er en insider fortælling om det irakiske folk og deres regering samt karakteren og omfanget af Iraks forværrede problemer.

Der tegnes et deprimerende billede af morderiske angreb, eskalerende sekterisme og afgrundsdyb regeringskorruption, der tilsammen forhindrer fremskridt på afgørende områder som sikkerhed, sundhed og energiforsyning. Al-Ali argumenterer for, at den dårligt planlagte amerikanske invasion ødelagde den irakiske stat og skabte et sort hul, som korrupte og inkompetente medlemmer af eliten har udnyttet. Men trods alle forsøg på at splitte dem, mener forfatteren, at irakerne har bevaret en stærk følelse af national identitet. Han nyvurderer Iraks forhold til sig selv, inspirationen fra begivenheder som det arabiske forår og redefinerer Iraks vigtigste kamp, at generobre levedygtighed som nation.

Vibeke Sperling er udenrigskorrespondent ved dagbladet Politiken og redaktør af bog noterne. 
Amoroso, Bruno \& Jesper Jespersen: Europa? Den udeblevne systemkritik. Politisk Revy. Ræevens Sorte Bibliotek, 2014.

En kritisk pamflet udgivet op til Europaparlamentsvalget i maj 2014 om EU's fremtid af to førende økonomer, en italiensk og en dansk. Blandt de påtrængende opgaver for Europa i dag ser forfatterne at genrejse den radikale systemkritik både på nationalt og fælles europæisk plan. Preben Wilhjelm skrev om teksten: "Vil man have svar på nogle spørgsmål, journalister aldrig stiller, kan man bare læse Bruno Amoroso og Jesper Jespersens pamflet."

Blanchard, Christopfer M., m.fl.:

Armed Conflict in Syria: Overview and U.S. Response. Congressional Research Service, 2014.

Kampene, der fortsætter på tværs af Syrien, sætter regeringsstyrker og deres udenlandske allierede op imod en stribe anti-regerings oprørere, hvor af nogle også bekæmper hinanden. Siden marts 2011 har konflikterne drevet over 2.7 millioner syrere på flygt ind i nabolande (ud af en samlet befolkning på over 22 millioner).Desuden er millioner internt fordrevne og har behov for humanitær hjælp, som USA er den største bilateral donor af med indtil bogens udgivelse til en værdi af 1.7 milliarder dollar.

Hverken pro-Assad styrker eller deres modstandere synes i stand til at konsolidere landvindinger eller opnå klare sejre på kort sigt, påviser forfatterne. Konflikter mellem Den Islamiske Stat Irak og Levanten (ISIL også kaldet ISIS) og andre anti-Assad styrker er intensiveret. Bogen tegner også et billede af, hvordan krigen i Syrien har pisket til sekterisme og politiske konflikter i Libanon og Irak til fare for den nationale sammenhængskraft også i de lande.
Branner, Hans:

Kloden rundt - problemstillinger i global politik. Forlaget Columbus, 2014.

Bogen omhandler fem temaer på kloden, hvor store igangværende eller potentielle konflikter finder sted, og hvor vigtige ændringer af global betydning er i gang. Ved hvert tema søges svar på et centralt hovedspørgsmål. Bogen er i undervisningssammenhæng med til at gøre faget international politik konkret og aktualitetsbetonet og egnet som supplement til mere generelle grundbøger.

Clinton, Hillary Rodham:

Hard Choices. På dansk: Svære Valg. Politikens Forlag, 2014.

Erindringsbog, hvori hun fortæller om sine fire år som USA's udenrigsminister.

"Vi må alle træffe hårde valg i vort liv. Livet handler om at træffe valg. Vore valg og hvordan vi har med dem at gøre, former de mennesker, som vi bliver," skriver hun i bogen, som er fremhævet for ikke at fortælle meget nyt, men formentlig skal tjene Clintons præsidentambitioner. Hun fortæller blandt andet om, at hun blev meget overrasket, da Barack Obama som nyvalgt præsident udvalgte hende, hans tidligere rival til præsidentposten, til udenrigsministerposten. Derudover fortæller hun om de udfordringer, hun har stået over for i forbindelse med konflikter, revolutioner og kriser i Iran, Nordkorea, Mellemøsten, Afghanistan og Libyen samt om forholdet til stormagter som Kina og Rusland.

Dasgupta, Rana:

Capital: The Eruption of Delhi. Penguin Press, 2014.

Den prisvindende forfatter undersøger tendensen i vor tid, at den globale elite ekspanderer. Bogen er et portræt af Delhi, der viser den ekstraordinære transformering af 
Indiens hovedstad. Historien om Delhi siger ifølge forfatteren en masse om, hvordan vi alle vil komme til at leve senere i det 21. århundrede. Det boom, som fulgte åbningen af Indiens økonomi, kastede Delhi ud i et virvar af ødelæggelse og nyskabelse. Slum og markeder blev fejet bort og butikscentre og boligblokke skød op fra ruinerne. Men transformeringen var barsk og enormt ulige og skabte grobund for mærkelige og forvirrede følelser. Byen sydede af ambitioner og raseri og volden stjal avisoverskrifterne. I en stil, der er sammenlignet med V. S. Naipauls nu klassiske Personlige Rejser, skildrer Dasgupta Delhi gennem dens indbyggeres øjne. Han taler med milliardærer, bureaukrater, narko- og skrothandlere, slumbeboere og psykoanalytikere om den ofte skrækindjagende kapitalistiske transformation.

Dahl, Ann-Sofie \& Pauli Järvenpää (red.): Northern Security and Global Politics: Nordic-Baltic strategic influence in a post-unipolar world. Routledge Global Security Studies, 2013.

Bogen ser på sikkerhed i den nordisk-baltiske region og hvordan den påvirkes af udviklingen I det internationale system. Det nye årtusindes komme faldt sammen med, at det høje nord vendte tilbage på den internationale scene. Flere faktorer har bidraget til den stigende internationale interesse for Europas nordlige del. Herunder isens smeltning på Grønland og i Arktis, som åbner for ressourcer og nye sejlruter. Forfatterne beskriver, at verden ikke længere er "unipolar", men endnu ikke "multipolar," måske "postunipolar", en flydende periode med afvikling af USA's hegemoni. Centrale analytikere på feltet udforsker, hvordan den situation har påvirket den nordisk-baltiske region ud fra to sæt af spørgsmål. For det første hvilken indflydelse den aftagende unipolaritet med større vægt for Asien, en reduceret rolle for
Europa i amerikansk politik og et mere selvhævdende Rusland vil få for den nordisk-baltiske sikkerhed. For udforsker bidragyderne, hvordan de regionale aktører svarer på disse ændringer på det strategiske område

Fruensgaard, Jonas:

Brasiliens forvandling, den nye stormagt bag facaden. Forlaget Mellemgaard, 2014.

Brasilien er inde i en rivende udvikling. Men indadtil står landet overfor store udfordringer, som truer dets videre udvikling. I denne bog tegnes et nærgående portræt af Brasiliens forvandling. Bogen går både bag om det store lands udvikling inden for økonomi, politik, kultur og religion og stiller skarpt på befolkningens levevilkår, udfordringer og muligheder.

Mian, Atif \& Amir Sufi:

House of Debt. How They (and You) Caused the Great Recession, and How We Can Prevent It from Happening Again. University og Chicago Press, 2014.

Den amerikanske recession resulterede i tabet af otte millioner arbejdspladser mellem 2007 og 2009. Mere end fire millioner hjem gik tabt for gældsatte og den samlede gæld for amerikanske husstande fordobledes mellem 2000 og 2007 til 14.000 milliarder dollar.

Ud fra klare og magtfulde beviser afslører forfatterne, at den store recession og depression lige som de aktuelle økonomiske problemer i Europa, var skabt af en massiv acceleration i husstandsgæld efterfulgt af et betragteligt fald i husstandsforbrug.

Det var bankkrisen, som erobrede offentlighedens opmærksomhed, men forfatterne argumenterer for, at den stærke fokus på at beskytte banker og kreditorer var katastrofalt kontraproduktivt, når det fundamentale problem var for megen gæld. En sådan cyklus kan kun brydes med et direkte angreb på gælden, ifølge Mian and Sufi. 
Nalbandov, Robert:

Democratization and Instability in Ukraine, Georgia, and Belarus. US Army Strategic Studies Institute (ISS), 2014.

Analyse af sammenhængen mellem demokratisk institutionsskabelse i Ukraine, Georgien og Hviderusland, deres politiske stabilitet eller mangel på samme samt økonomiske udvikling. Ved hjælp af begrebet 'efterligning' inden for den offentlige administration, udvides den erkendelsesteoretisk ramme for demokratiseringsskolen til at omfatte fænomenet politisk kultur. Succeser og fejl under den demokratiske institutionsbyggeproces i de pågældende lande afhænger i vidt omfang af, hvordan de institutionelle aktører har reageret på interne og eksterne vanskeligheder for deres hjemlige politiske, økonomiske og kulturelle situation. Det afdækkes, at Georgiens politiske kultur har vist den største grad af fleksibilitet i accept af forslag udefra om institutionelle rammer og praksis, den tvedelte politiske kultur i Ukraine har forhindret demokratisk institutionsbygning, mens den rigide politiske kultur i Hviderusland helt har bremset processen for institutionelle transformationer.

Rostampour, Maryam \& Marziyeh Amirizadeh:

Captive in Iran: A Remarkable True Story of Hope and Triumph amid the Horror of Tehran's Brutal Evin Prison. Tyndale Momentum, 2014

De to forfattere vidste, at de satte livet på spil. Irans islamiske lov forbød dem at udbrede deres kristne tro, men i tre år uddelte de Det Nye Testamente til 20.000 af deres landsmænd og skabte to hemmelige kirker i private hjem. De blev arresteret i 2009 og indsat i Teherans berygtede Evin Fængsel, hvor tortur og henrettelser er dagligdag. Men trods brutal forfølgelse tog de det radikale skridt at udbrede deres tro også bag fængselsmurene. De fortæller, at de brugte de 259 dage i Evin til "at lade Guds lys skinne over et af verdens mørkeste steder".

Feifer, Gregory:

Russians: The People behind the Power. Twelve, 2014.

Den tidligere Moskva-korrespondent trækker på mange levende personlige historier for at skildre de kræfter, der har formet den russiske karakter i århundreder og fortsætter med at gøre det. Han udforsker tilsyneladende paradokser i livet i Rusland, der siger meget om russernes karakter. Feifer søger svar på spørgsmålet, hvad det er i russernes historie, drømme og selvopfattelse, der gør dem så forvirrende for Vesten.

Ud fra personlige erfaringer fra et årti som journalist i Rusland gør Feifer op med mange misopfattelser ved at vise, at meget som synes uforklarligt om landet er logisk set indefra. Han gør også klart, hvorfor Vladimir Putin er forblevet så populær, selv om kløften mellem de superrige og flertallet af hel- eller halvfattige bliver stadig større.

Bogen er en rejse gennem verdens arealmæssigt største land fra Nordkaukasus til det arktiske Sibirien og møder med alle lag fra de kolossalt rige oligarker til de gamle babusjkaer (bedstemødre), der tigger i Moskvas gader. Det er historien om et samfund af enorm vitalitet og desperation under et lederskab med dybe rødder i traditioner og konservatisme. Det er også Feifers egen familiehistorie om hans russiske mor, der voksede op i Moskvas kunstnerelite, til hans amerikanske fars vodkapåvirkede konfrontationer med KGB.

Gall, Carlotta:

The Wrong Enemy: America in Afghanistan, 2001-2014. Houghton Mifflin Harcourt, 2014. 
Carlotta Gall rapporterede fra Afghanistan og Pakistan i næsten hele perioden fra kort efter 9/11. Hun har levende beskrevet omkostningerne ved den amerikanske invasion for afghanerne og den negative indflydelse på Pakistan. I lyset af den amerikanske tilbagetrækning fortæller bogen historien om, hvordan vi har bekæmpet 'den forkerte fjende i det forkerte land'.

Gall kombinerer personlige historier om kampe og forræderi med bevægende portrætter af almindelige afghanere, førstehåndsfortællinger om Talebans krigsherrer, pakistanske efterretningsgangstere, amerikanske generaler, afghanske politikere og de mange uskyldige ofre. Bogen bringer også nye beviser for, at Pakistan støttede Taleban og beskyttede Osama bin Laden. Det er fortællingen om amerikanske ledere med gode intentioner imod en fjende, som de dårligt forstod og ikke kunne komme på talefod med.

Guha, Ramachandra:

Gandhi Before India. Knopf, 2014.

Forfatteren er af Time hyldet som "Indisk demokratis mest fremragende kronikør". Bogen beskriver Gandhis liv fra fødslen i 1869, hans opvækst i Gujarat, to år som studerende i London og hans to årtier som advokat og aktivist i Sydafrika. Guha har fremskaffet myriader af tidligere ukendte dokumenter som private papirer fra Gandhis samtidige, skriverier fra hans børn og hemmelige dokumenter hos tidligere embedsmænd i det britiske imperium. Guha beskriver den politiske, sociale og personlige verden, som Gandhi foretog den rejse i, som gav ham Mahatma æren. Bogen viser tydeligt, hvordan Gandhis arbejde i Sydafrika havde dyb indflydelse på hans udvikling som familiemand, politisk tænker, social reformaktivist og elsket leder. I 1893 rejste han til Sydafrika som 23-årig advokat, fordi det var mislykket ham at etablere sig i Indien. Han vendte tilbage i 1915 med klare ideer om imperialismens og racismen væsen, som han også studerede i England.
Halasa, Malu, Zaher Omareen \& Nawara Mahfoud (red.):

'SYRIA SPEAKS' - Art and culture from the frontline. Saqi Books, 2014.

Redaktørerne bag antologien kalder den et vidnesbyrd om det syriske folks mod, kreativitet og fantasi. Over 50 kunstnere og skribenter i og uden for Syrien har bidraget med digte, noveller, personlige beretninger, fotografier, tegninger og plakater

skabt før og under den syriske krig. Herunder den forfulgte forfatter Khaled Khalifas historie om søsterens død, Khalil Younes illustrationer af den revolutionens frontfigurer, Yara Badrs personlige beretning om to generationers fængslinger, satiretegner Ali Ferzats skarpe streger og kollektivet Alshaabs plakater giver sammen med Sulafa Hijazis rå illustrationer af krigens vold og barske personlige konsekvenser.

Heier, Tormod m.fl.:

Alike or Different? Scandinavian Approaches to Military Interventions. Santérus Academic Press, 2014.

Bogen sammenligner strategiske beslutninger i Danmark, Norge, Finland og Sverige. Trods forskellige erfaringer under Anden Verdenskrig opfattes sikkerhedspolitik i de fire lande som regel som styret af en lignende skandinavisk identitet. Men holdningen til EU og Nato, når det gælder sikkerheds- og forsvarspolitik, er ikke så ens endda, viser bogen med bidrag fra forskere $i$ alle de fire lande.

Høgh-Sørensen, Erik:

Mod Vinden. Danmarks plads i Europa. Nyt Nordisk Forlag, 2014.

Som Ritzaus korrespondent i Bruxelles var forfatteren den første journalist, der kunne afsløre Anders Fogh Rasmussens ambitioner om et europæisk topjob. Dette og andre forløb gennemgås i bogen Mod vinden 
- Danmarks plads i Europa, der afdækker, hvordan Foghs personlige ambition fik varig betydning for Danmarks rolle i Europa. Bogen giver også et førstehånds-indblik i, hvordan svært forståelige traktater i sidste ende påvirker alle danskeres hverdag inden for felter som konkurrencejura, udenrigspolitik, forbrugerbeskyttelse, landbrug og fiskeri. De danske EU-forbeholds rolle i dagligdagen analyseres, og bogen kaster nyt lys på Muhammedkrisens forløb. Erik HøghSørensen har lavet langt over 7.000 artikler og radioindslag om EU. Han er kritisk over for de danske mediers dækning af EU.

The International Institute for Strategic Studies:

Military Balance, 2014.

The International Institute for Strategic Studies, IISS 2014. Bogen har ud over sammenlignende statistik over personel og militære udgifter i de 171 lande, som den dækker, en grundig gennemgang af de enkelte landes militære forhold. Der er oplysninger om landenes militære organisering, antal soldater, militært udstyr fordelt på typer og relevante økonomiske og demografiske data. Det er også her, man hurtigt kan se, hvor mange kvinder der deltager i væbnede konflikter verden over. Der er i dag 250.000 militære køretøjer i aktiv tjeneste i de 171 omhandlende lande.

McHugo, John:

Syria: From the Great War to Civil War. Saqi Books, 2014.

Syriens nedtur til borgerkrig har taget anslået 150.000 liv, mens næsten ni millioner er flygtet fra deres hjem. Det er nu den største humanitære og politiske krise i det 21- århundrede, skriver forfatteren. McHugo analyserer, hvorfor Syriens grundlag som nation har vist sig så skrøbeligt. Ved at følge historien fra Første Verdenskrig til i dag blotlægges den nuværende tragedie: Landets forkvak- lede forsøg på uafhængighed, arven fra den anglo-franske deling, som fragmenterede Syrien og den fejlslagne franske politik. McHugo vender sig derefter til de de seneste religiøse og sekteriske spændinger, presset fra den kolde krig og den arabisk-israelske konflikt og to generationers Assad styre. Bogens svar på spørgsmålet 'Fik Syrien nogensinde en chance?' er pinagtige for både vesterlændinge og arabere.

Morris, Ian:

War! What is it Good For? The Role og Conflict in Civilization, from Primates to Robots. Profile, 2014.

Forfatteren, der er arkæolog og historiker, beskriver krigen gennem menneskehedens historie helt fra primatniveauet over historisk tid og frem til i dag. Herunder det historiske paradoks, at krige har muliggjort fred. Bogen rejser det aktuelle spørgsmål, hvad krig indebærer, når teknologiske fremskridt har gjort våben så destruktive, at de truer de krigsførendes eksistensgrundlag med atombomber som det ultimative våben.

Mousavian, Seyed Hossein \& Shahir Shahudsaless:

Iran and The United States: An Insider's View on the Failed Past and the Road to Peace. Bloomsbury Academic, 2014.

Der er skrevet et utal af bøger af vestlige og især amerikanske eksperter om rødderne til konflikten mellem Iran og USA. Denne skiller sig ud ved at være insideres blik på de komplicerede relationer internt i iransk kultur og samfund samt det iranske politiske system. Seyed Hossein Mousavian har arbejdet i 30 år med diplomatiske bestræbelser mellem Iran og Vesten og har haft adskillige officielle poster og nære relationer til højtstående iranske embedsmænd som nuværende præsident Hassan Rouhani og udenrigsminister Javad Zarif. Førstehåndsbe- 
skrivelser er blandet med erindringer og analyser. Bogen indeholder mange nye detaljer om de mange mistede muligheder for tilnærmelse og afsluttes med en mulig vejviser til fred, som forfatterne fremhæver, at begge parter har desperat behov for.

Kierulf, John:

Nedrustning - i et folkeretligt perspektiv. Jurist- og økonomforbundets Forlag, København, 2014.

John Kierulfs bog er den første omfattende beskrivelse på dansk af den folkeretlige regulering af nedrustning, våbenkontrol og ikke-spredning af såvel masseødelæggelsesvåben som konventionelle våben. Bogen giver en introduktion til nedrustningsretten, som består af folkeretlige regler om nedrustning, våbenkontrol og ikke-spredning, der er fastlagt i traktater, konventioner og andre internationale aftaler. Desuden gennemgås nedrustningsaftalernes folkeretlige baggrund, sammenhæng, historiske udvikling og indgåelse, og aftalernes fortolkning, overholdelse og håndhævelse beskrives. Lovligheden af atomvåben diskuteres på baggrund af Den Internationale Domstols vejledende udtalelse herom. I bogens politiske efterskrift findes en oversigt over Danmarks nedrustningspolitik samt oplysninger og kommentarer om Danmarks indsats på nedrustningsområdet.

Lendman, Stephen (red.):

Flashpoint in Ukraine: How the US Drive for Hegemony Risks World War III. Clarity Press, 2014.

Bogen beskriver udviklingen i Ukraine som nutidens alvorligste geopolitiske krise, der har potentiale til at udløse en tredje verdenskrig. Set ud fra vestlige mainstreammedier, opstod krisen på grund af prodemokratiske aktivisters nedkæmpelse af et brutalt diktatur, som hurtigt ledte til den russiske overtagelse af Krim. Men set ud fra de 22 fremtrædende analytikere, der bidrager til denne antologi, er det i virkeligheden en ganske anden historie: Obamas omdrejningsakse er global i bestræbelserne for uantastet verdensdominans, der fører til en række åbne krige og krige per stedfortræder. Det neokonservativt dominerede Washington søger at marginalisere rivalerne Rusland og Kina, som begge er omringet af amerikanske baser. Ukraine er i stormens øje som kronjuvelen for NATO's ekspansion østover som sidste skridt til at inkorporerer alle tidligere sovjetrepubliker i NATO og installere missilforsvar ved Ruslands grænse. Til den ende har USA ifølge antologien postet fem milliarder dollar i demokratibevægelser i regionen, herunder Ukraine. Imod den almindelige opfattelse er det ifølge denne udgivelse ikke en russisk trussel om ny imperialisme, men den amerikanske imperialisme, som udgør den største fare "for ikke bare borgerkrig i Ukraine og en potentiel øst-vest konfrontation men også for global atomkrig”.

Mearsheimer, John J.:

The Tragedy of Great Power Politics. Norton \& Company, opdateret udgave, 2014.

Forfatteren ser på spørgsmålet, som ventes at dominere internationale relationer $\mathrm{i}$ det 21. århundrede: Kan Kina rejse sig på fredelig vis? Svaret er nej fra Mearsheimer, der mener, at Kina vil søge at dominere Asien, mens USA er besluttet på at bevare hegemoni og vil strække sig langt for at forhindre kinesisk dominans i Asien. Storpolitikkens tragedie er derfor uundgåelige, ifølge bogen. Nogen 'fredsdividende' eller 'familie af nationer' kan der ikke blive tale om, i stedet en slags darwinistisk tilstand: "Stormagterne søger at maksimere deres andel af magten i verden, fordi dominerende magt ses som den bedste måde at sikre egen overlevelse". Mearsheimer kalder sin 
egen tankegang "offensiv realisme" og advarer gentagne gange imod troen på goodwill fra andre lande: "Den triste kendsgerning er, at international politik altid har været brutal og farlig business". Meget af bogen forsøger at vise, hvordan de sidste to århundreders diplomatiske og militære historie underbygger hans teorier, der leder ham til at konstatere, "at de eksisterende magtstrukturer i Europa og Nordøstasien ikke er bæredygtige frem til 2020." Mearsheimer er specielt kritisk over for USA's politik for at engagere Kina, da han mener, at forsøgene på at gøre Kina rigt og demokratisk kun kan gøre det til en stærkere rival.

Nauntofte, Jens:

Verden og den arabiske udfordring - følgerne af det arabiske forår. Systime, 2014.

Den tidligere Mellemøstkorrespondent for DR's Orientering og TV-avisen, beskriver i denne bog følgerne af den uventede eksplosion af frihed, Det Arabiske Forår, med katastroferne, som fulgte efter i Syrien og Irak med Den Islamiske Stat, IS, der er i færd med at ændre det mellemøstlige kort med en ny stat - et islamistisk kalifat.

Det nordvestlige Irak er nu under kontrol af terrorgrupperne i den islamistiske kampgruppe IS. Jens Nauntofte sætter denne nye krise i perspektiv i bogen, som er skrevet til undervisningsbrug, men den giver overblik for alle, der ønsker at forstå den dramatiske udvikling efter håbets tid om frihed i arabiske lande. Bogen er rigt illustreret, forsynet med faktabokse og uddrag af forfatterens egne interview med centrale personer. Nauntofte forklarer, hvad der er sket i Irak og Syrien og hele Mellemøsten efter Det arabiske Forår og analyserer stormagternes afmagt overfor den nye blodige udvikling.

Bogen beskriver de oprørsramte arabiske lande samt de ikke-arabiske medspillere og berørte lande: Israel, Iran og Tyrkiet. Der er lagt særlig vægt på USA’s mellem- østenpolitik samt Ruslands politik i regionen, ikke mindst i forhold til Syrien, Libanon og Iran.

Nauntofte citerer i forordet en syrisk tweet: "Læs skriften på væggen, gamle mand! Enhver arabisk leder kan blive afsat hvad dag det skal være. Det er os, der vælger tidspunktet. Sov godt!"

USA har bombet IS's stillinger i Irak, og Danmark har som flere andre europæiske lande sendt fly med våben og nødhjælp til de truede områder i Irak. Der er begrundet frygt for, at IS's aggressive krigsførelse skal involvere nabolandene Syrien, Libanon og Jordan. Som det hedder i præsentationen af bogen: "Det er en politisk katastrofe af uventet omfang, hvor der fra Syrien sendes dræbende metastaser ud i Mellemøsten. Ingen arabisk stat kan roligt se på, mens denne terrorstat udvikler sig for øjnene af dem. Samtidig søger syriske flygtninge i titusindtal til Europa. Halvdelen af den syriske befolkning er på flugt, og da nabolandene selv er ramt af krisen, betyder det at flygtningepresset mod Europa stiger". Men størst synes faren for vestlige lande at være radikalisering fra de mange også vestlige IS-krigere, som vender hjem.

\section{Petersen, Jørgen E:}

De sorte kinesere. Kina, Afrika og Europa. Kahrius.dk Forlagsaktieselskab, 2014.

Den mangeårige leder af DR's Orientering og korrespondent i Sydafrika og Frankrig, Jørgen E. Petersen, har rejst rundt i Afrika i mere end 50 år. Dette er hans 12. bog med afrikansk perspektiv. I 'De sorte kinesere' giver han udtryk for frygt for konsekvenserne af Kinas kolonisering af det sorte kontinent og argumenterer for et udvidet, formaliseret samarbejde mellem EU og Den Afrikanske Union. På grundlag af en række kilder fremhæver han svagheder i Kina og kinesisk politik, der har konsekvenser for Afrika og Europa. Forfatteren peger bl.a. på, at kinesisk censur invaderer vestlig kultur i den- 
ne den hidtil mest omfattende og grundige redegørelse på dansk for Kina stadig mere massive tilstedeværelse i Afrika. Bogen rummer desuden en udførlig oversigt over de enkelte afrikanske stater.

Porter-Szücs, Brian:

Poland in the Modern World: Beyond Martyrdom. A New History of Modern Europe. Wiley-Blackwell, 2014.

En historie om Polen fra sidst i det 19. århundrede til i dag, som kaster nye perspektiver over det sociale og kulturelle liv ud fra almindelige levevilkår i landet, sat i en bred global kontekst. Porter-Szücs udforsker både den regionale diversitet $\mathrm{i}$ Polen og dets placering i Europa og globalt og han udfordrer traditionelle, nationalistiske fortællinger om heroisme og tragedier. Om den historiske baggrund beskrives dagligdagens relationer mellem polakker med forskellig religion og sprog mellem de to verdenskrige, livet $\mathrm{i}$ Warszawas ghetto og hvad Stalins industrielle ekspansion betød for bønder, der tog fabriksarbejde sent i 1940'erne og tidligt i 1950'erne samt ændringer i begreberne om maskulinitet og femininitet over tid. Bogen fremhæves som en nuanceret historisk oversigt, der anerkender både særegenheder og universalitet i det moderne Polens historie.

Gostyńska, Agara, Paweł Tokarski, Patryk Toporowski \& Damian Wnukowski (red.):

Eurozone Enlargement in Times of Crisis: Challenges for the V4 Countries.

Polish Institute of International Affairs, 2014.

Artikelsamlingen er resultat af Rastanews projektet "Makrorisici vurdering og stabiliseringspolitik ud fra nye tidlige faresignaler." De 11 artikler er skrevet af repræsentanter for tænketanke og universiteter samt bankfolk, der vurderer udvidelsen af eurozonen ud fra økonomiske, politiske og juridiske perspektiver. Publikationen har til hensigt at bidrage til debatten om central- og østeuropæiske lands overgang til euro, ud fra analyser af Slovakiets erfaring og faktorerne bag situationen i Polen, Tjekkiet og Ungarn.

Rose, Gideon (red.):

Crisis in Ukraine. Council on Foreign Relations, 2014.

Bogen sætter den intellektuelle scene til forståelse af kaos i Østeuropa, hvad der er på spil og hvad, som efterfølgende kan ventes. Argumenterne i bogen spænder over hele det ideologiske spektrum og blandt forfatterne er eksperter fra forskelle discipliner og lande, herunder Julia Timosjenko, Alexander Motyl, Orlando Figes, Kathryn Stoner, Daniel Treisman, Brian Taylor og Kathleen McNamara. Mens politikere i vestlige hovedstæder diskuterer, hvad der skal stilles op med Ukraine, søger bogen at sætte læseren i stand til at danne egne meninger.

Rasmussen, Lars Toft:

USA på tværs, med forord af Kristian Mouritzen. Forlaget Kleart, 2014.

Trods mange års eksponering til USA følte journalisten Lars Toft Rasmussen, at han kun kendte halvdelen af amerikanerne. Hans omgangskreds bestod udelukkende af rettænkende 'liberale' - i den amerikanske betydning af ordet - der mener alt 'det rigtige', og som trofast stemmer på det demokratiske parti. Derfor besluttede han at krydse USA på cykel - og undervejs mødte han en noget anderledes virkelighed.

Stepanov, Alexander:

Ukraine: The Cold War that Never Ended. Amazon Digital Services Inc, 2014.

I forsøg på at forhindre genetablering af en form for Sovjetunionen pressede EU og USA en associeringsaftale med Ukraine igennem 
med EU, som tidligere ukrainske præsident Viktor Janukovitj sprang fra. Det førte ifølge forfatteren til "et blodigt kup", som startede et "terrorregime", som fik flere ukrainske regioner til at søge løsrivelse fra Kijev. Bogen udforsker de historiske, politiske, økonomiske og kulturelle forhold, at førte til katastrofen..

Sanchez, Juan Reinaldo:

La Vie Cachée de Fidel Castro. Michel Lafon, 2014.

Bogen er skrevet af en af Fidel Castros yndlingslivvagter gennem 17 år, som ikke lægger fingrene imellem. Fidels forhold til de latinamerikanske guerillaer oprulles og han 'afsløres' som indblandet i narkohandel. Fidels offentlige image som en asketisk mand med få besiddelser, er fuldkommen falsk, ifølge livvagten. Det, som Castro kalder sin lille fiskerhytte, er i virkeligheden en pragtvilla, hvor han spiser kostbart skildpaddekød, importeret kun til ham, og sejler i luksusyacht. Han har angiveligt mere end 20 huse rundt om i Cuba, hvor han har mødt sine utallige elskerinder. Livvagten fortæller også, at Fidel har en dobbeltgænger, der har været benyttet de to gange, Fidel var døden nær. Fidel er tyrannisk, lunefuld, paranoid og beregnende, ifølge forfatteren til bogen, der er skrevet i samarbejde med Axel Gylden, journalist ved det fransk L'Express. Livvagten fortæller, at Fidel direkte samarbejdede med de colombianske narkomafiaer med henblik på at smugle kokain til USA. Det forklarer også den berømte Ochoa-affære, hvor general Ochoa blev henrettet for narkosmugling.

Plokhy, Sehii:

The Last Empire. The Final Days of the Soviet Union. Basic Books, 2014.

Juledag 1991 talte USA's præsident George W. Bush til nationen og erklærede amerikansk sejr i den kolde krig. Tidlige- re samme dag havde Mikhail Gorbatjov trukket sig tilbage som Sovjetunionens første og sidste præsident. Den fortælling, at afslutningen på den kolde krig var udslag af triumfen for demokratiske værdier over kommunisme, blev fasttømret i den amerikanske offentlighed af Bushs tale og holdt ved i årtier med ifølge forfatteren katastrofale konsekvenser for USA i verden. Den prisvindende historiker Plokhy afdækker, at Sovjetunionens sammenbrud var alt andet end USA's fortjeneste. Tværtimod frygtede amerikanske ledere muligheden for, at Sovjetunionen, der var svækket af intern strid og økonomisk kaos, pludselige ville falde sammen og kaste hele det eurasiatiske område ud i kaos. Bush støttede sin allierede og personlige ven Gorbatjov og var skeptisk over for den da nyvalgte russiske præsident Boris Jeltsin. Af frygt for hvad der kunne ske med de enorme sovjetiske atomarsenaler, hvis Sovjetunionen brød sammen, støttede Bush længe Gorbatjovs modstand imod de stadig stærkere uafhængighedsbevægelser i Baltikum, Ukraine og Kaukasus. Plokhy viser, at det først var efter, at uafhængighedsbevægelserne havde fået uafvendelig styrke op til Ukraines afstemning for uafhængighed, at Bush endelig overlod Gorbatjov til sin skæbne. Ud fra nyligt afklassificerede dokumenter og egne interview med centrale deltagere om Sovjetunionens sidste måneder argumenterer Plokhy for, at sammenbruddet var uundgåeligt, fordi de to største sovjetrepublikker, Ukraine og Rusland, ikke kunne enes om, hvordan er forenet stat skulle se ud. En konflikt, som har genklang i den nuværende russisk-ukrainske konflikt.

At tolke sammenbruddet som USA's fortjeneste var ikke kun en myte, men det førte til overvurdering af USA's evne til at nedkæmpe og genopbygge fremmede regimer og "har plaget amerikansk udenrigspolitik lige siden". 
Scheller, Bente:

The Wisdom of Syria's Waiting Game: Foreign Policy Under the Assads. Hurst, 2014.

Syriens udenrigspolitik, der altid har været uigennemskuelig, er blevet et stadig mere kompliceret puslespil under den syriske opstand. På trods af regimets internationale isolation i kølvandet på dets brutale svar på hjemlig protest, har hyklerisk støttet internationale fredsplaner, mens det uophørligt har søgt at smadre oprør. Præsident Assads sjældne optrædener på tv har vist en leder, der er helt afkoblet fra virkeligheden. I denne bog fra veteranen blandt analytiker og tidligere diplomat Bente Scheller påvises, at Bashar Assads dødelige ventespil følger sin egen logik: Hvilke vanskeligheder regimet end møder er dets tidligere erfaringer, at det simpelthen kan sidde og vente til krisen er drevet over.

Valeur, Henrik:

India: the Urban Transition - a Case Study of Development Urbanism. The Architectural Publisher, 2014.

Den danske arkitekt og urbaniseringsekspert, der længe har forsket, undervist og drevet feltstudier i Indien, fokuserer på bæredygtig byudvikling som et middel til at bekæmpe fattigdom og beskytte miljøet i udviklingslande. Han diskuterer nogle af problemerne ved urbanisering, når 500 millioner flytter til indiske byer. Det gælder bl.a. luftforurening, forurening af vandressourcerne, fødevareproblemer, boligmangel samt miljø- og sundhedsproblemer som følge af trafikken. Valeur foreslår også en række mulige løsninger som brug af planter og naturlig ventilation for bedre indeklima, genopbygning af et eksisterende system af vandkanaler, vertikale køkkenhaver i rehabiliteringskolonier, en strategi for bilfri bykvarterer og billigt, selvdesignet boligbyggeri.
Watson, Alexander:

Ring of Steel: Germany and AustriaHungary in World War I. Basic Books oktober, 2014.

For Tyskland og Østrig-Ungarn startede Første Verdenskrig med høje forventninger om en hurtig endelig afgørelse, men trods de første vanskeligheder for den russiske invasion, blev centralmagternes planer hurtigt ødelagt. Alexander Watson genfortæller krigen ud fra dens anstiftere og taberes perspektiv. Det er en historie om ikke blot lederne i Berlin og Wien men endnu mere om befolkningerne. Kun gennem en mobilisering uden sidestykke kunne krigen vare så længe og udkæmpes så bittert.

Winkel, Klaus:

Udvikling - om Danmarks bistand. Forlaget Frydenlund, 2014.

Forfatteren har arbejdet i Danida fra den spæde start til et stykke op i 2000erne. I bogen tager han den danske bistandspolitik under håndfast behandling og opfordrer til, at dansk udviklingsbistand igen skal kunne gøre en forskel. Dette vil kræve nytænkning, mener han. Bogens første del består af erindringer fra et liv i Danida og med dansk bistandspolitik. I anden del lægger han op til debat.

Ytzen, Flemming \& Mikael Gravers (red.): Burma/Myanmar - Where now? Forlaget Nias Press, 2014.

Forandringerne i Burma/Myanmar er blevet kaldt "det burmesiske forår". De internationale medier har hovedsageligt fokuseret på de mange nye økonomiske muligheder, som forandringerne baner vejen for. Men realteterne er langt mere komplicerede. Landets er meget fattigt og opdelt af etniske og religiøse skillelinier, mens kredse inden for en magtfuld elite modsætter sig reformer. Hvor er landet på vej hen?

o 00 